\title{
Assessing the utilization of naturalized alien plant species by community to inform its management strategy: A case study in Cibodas Biosphere Reserve, West Java, Indonesia
}

\author{
AISYAH HANDAYANI ${ }^{1,3, \vartheta}$, ERVIZAL A.M. ZUHUD ${ }^{2, v v}$, DECKY INDRAWAN JUNAEDI ${ }^{3}$ \\ ${ }^{1}$ Natural Resources and Environmental Management Science Program, Graduate School, Institut Pertanian Bogor. Jl. Raya Pajajaran, Campus IPB \\ Baranangsiang, Bogor 16000, West Java, Indonesia. Tel.: +62-251-8332779, ”email: handayani88aisyah@apps.ipb.ac.id \\ ${ }^{2}$ Department of Forest Resource Conservation and Ecotourism, Faculty of Forestry and Environment, Institut Pertanian Bogor. Jl. Lingkar Akademik, \\ Campus IPB Dramaga, Bogor 16680, West Java, Indonesia. Tel.: +62-251-8621677, Fax.: +62-251-8621256, "vemail: eamzuhud@ apps.ipb.ac.id \\ ${ }^{3}$ Cibodas Botanic Gardens, Research Center for Plant Conservation and Botanic Gardens, Indonesian Institutes of Sciences. Jl. Kebun Raya Cibodas, \\ Sindanglaya, Cipanas, Cianjur 43253, West Java, Indonesia
}

Manuscript received: 6 April 2021. Revision accepted: 7 June 2021.

\begin{abstract}
Handayani A, Zuhud EAM, Junaedi DI. 2021. Assessing the utilization of naturalized alien plant species by community to inform its management strategy: A case study in Cibodas Biosphere Reserve, West Java, Indonesia. Biodiversitas 22: 2579-2588. Alien plant species can have two side effects, either positively in terms of the utilization of these species to fulfill human needs, or negatively in terms of their invasion which might threaten biodiversity and reduce land productivity. Yet, it is not clear how an introduced plant species can be carefully managed and utilized (so-called Naturalized Alien Plant Species/NAPS) so that the NAPS does not become Invasive Alien Plant Species (IAPS). Using Cibodas Biosphere Reserves (CBR), West Java, Indonesia as a case study, this study aims to investigate the utilization of Naturalized Alien Plant Species (NAPS) by local communities in the buffer zone of CBR and quantify the utilization of NAPS based on cultural perspective using Index Cultural Significance (ICS) framework. Data were collected by distributing questionnaires and interviewing 90 respondents in three locations around CBR: Bodogol, Cibodas, and Gekbrong. The results showed that the community used 72 Naturalized Alien Plant Species, with $30 \%$ of the utilized plants were from Asteraceae family. Centella asiatica was the most widely used species, but the species with the highest Index Cultural Significance value was Artemisia vulgaris. Based on the ICS classification, there were ten species (13.89\%) with high significance values, 17 species (23.61\%) with moderate significance, 30 species (41.67\%) with low significance, and 15 species (20.83\%) with very low significance. Species with high significance values were Artemisia vulgaris, Chimonobambusa quadrangularis, Bidens pilosa, Mentha arvensis, Amaranthus spinosus, Centella asiatica, Cyphomandra betacea, Calliandra calothyrsus, Fragaria vesca, and Solanum torvum. Based on these results, the recommended strategy is to regularly harvest the Naturalized Alien Plant Species with high ICS value to control their population and fulfill community needs.
\end{abstract}

Keywords: Asteraceae, alien species management, Gunung Gede Pangrango National Park, Index Cultural Significance

\section{INTRODUCTION}

Invasive alien species (IAS) have negative impacts on native ecosystems (Jeschke et al. 2014). The impacts of IAS are determined by the level of species invasiveness and its biological characteristics, and are often worsened by human involvement and global climate change (Rai and Kim 2020). In protected areas, the impacts of IAS can be in the form of the domination of IAS over native species which leads to the extirpation of biodiversity at a landscape scale and the degradation of ecosystem services provided by the protected areas (Jeschke et al. 2014; Foxcroft et al. 2017; Rai and Kim 2020; Rai and Singh 2020). In productive landscapes, for example, agricultural lands, the invasion of IAS can significantly affect the productivity of the land which eventually reduces the capacity of the landscape in fulfilling human needs (Rai and Singh 2020; Rai and Kim 2020).

Invasive Alien Plant Species (IAPS) is plant introduced into a new region away from its original geographical distribution which can quickly spread and invade the new region (Knezevic 2017; Rai and Singh 2020; Pyšek et al. 2020). On the other hand, Naturalized Alien Plant Species (NAPS) is defined as plant introduced into a new location where it can survive, live under biotic and abiotic factors, and form a self-sustaining population without human intervention (Richardson et al. 2000; Pyšek et al. 2017). Richardson et al. (2000) stated that invasive plant refers to introduced plant that produces reproductive offspring in areas distant from the initial location of the introduction at an approximate scales of more than $100 \mathrm{~m}$ with time span of fewer than 50 years for taxa spreading by seeds and other propagules, or more than $6 \mathrm{~m}$ in three years for taxa spreading by roots, rhizomes, stolons or creeping stems. By that, the term invasive can be used without any inference to environmental or economic impact.

Kueffer (2017) said that human-related factors could facilitate the invasion of an introduced species and play an essential role in biological invasion mechanisms. Therefore, social and economic aspects, including the utilization of NAPS, can be important to control NAPS population to prevent it from becoming invasive (i.e., to 
avoid the NAPS becoming IAPS). Several studies showed that NAPS significantly contribute to fulfilling human needs such as food sources, medicinal uses, ornamental plants, fodders, firewoods, and other functional benefits (Zimdahl 2018; Shackleton et al. 2019; Shrestha et al. 2019). Similarly, several IAPS has the potentials to be used for phytoremediation and restoration of aquatic and terrestrial ecosystems, such as Lantana camara and Eichhornia crassipes (Rai and Singh 2015; Negi et al. 2019; Rai and Kim 2020). Other IAPS, such as Ageratina adenophora and Ipomoea carnea ssp. fistulosa can also be utilized to minimize flood and landslide risks (Shrestha et al. 2019).

While the definition between NAPS and IAPS can be clearly explained as mentioned above, the mechanism on how an introduced plant species is carefully managed and utilized so that the NAPS does not become IAPS is unclear. Using Cibodas Biosphere Reserves (CBR) as a case study, this study aims to investigate the utilization of Naturalized Alien Plant Species (NAPS) by local communities in the buffer zone of CBR and quantify the utilization of NAPS based on cultural perspective using Index Cultural Significance (ICS) framework (Turner 1988). There are only two studies on the utilization of alien plant species in CBR, i.e., alien plant species utilization study using secondary data (Handayani and Hidayati 2020) and ethnobotanical studies of Passiflora edulis at Sarongge (Setiawan et al. 2020). This study will complement the existing studies on alien plant species in CBR in the theme of species inventory (Mutaqien et al. 2011; Sunaryo et al. 2012; Kudo et al. 2014; Padmanaba et al. 2017), taxonomical studies (Damayanto and Muhaimin 2017) and ecological studies (Junaedi and Mutaqien 2018). We expect that through the social approach conducted in this study, proper management to prevent invasion risk of NAPS to become IAPS can be formulated.

\section{MATERIALS AND METHODS}

\section{Study location and period}

The study was conducted at three buffer zones of Cibodas Biosphere Reserve (CBR), namely Cibodas, Bodogol, and Gekbrong, which are directly located next to the CBR core zone (Gunung Gede Pangrango National Park forest areas) (Figure 1). The elevation of the sampling location in Bodogol was approximately $600 \mathrm{~m}$ above sea level ( $\mathrm{m}$ asl.), sampling location in Cibodas area ranged from 1100 to $1200 \mathrm{~m}$ asl and the Gekbrong sampling location was located at $1200 \mathrm{~m}$ asl. Sampling and data collection were conducted from August 2020 to September 2020 with activities including the arrangement of administrative permission from local government, the early survey to sampling locations, and data collections.

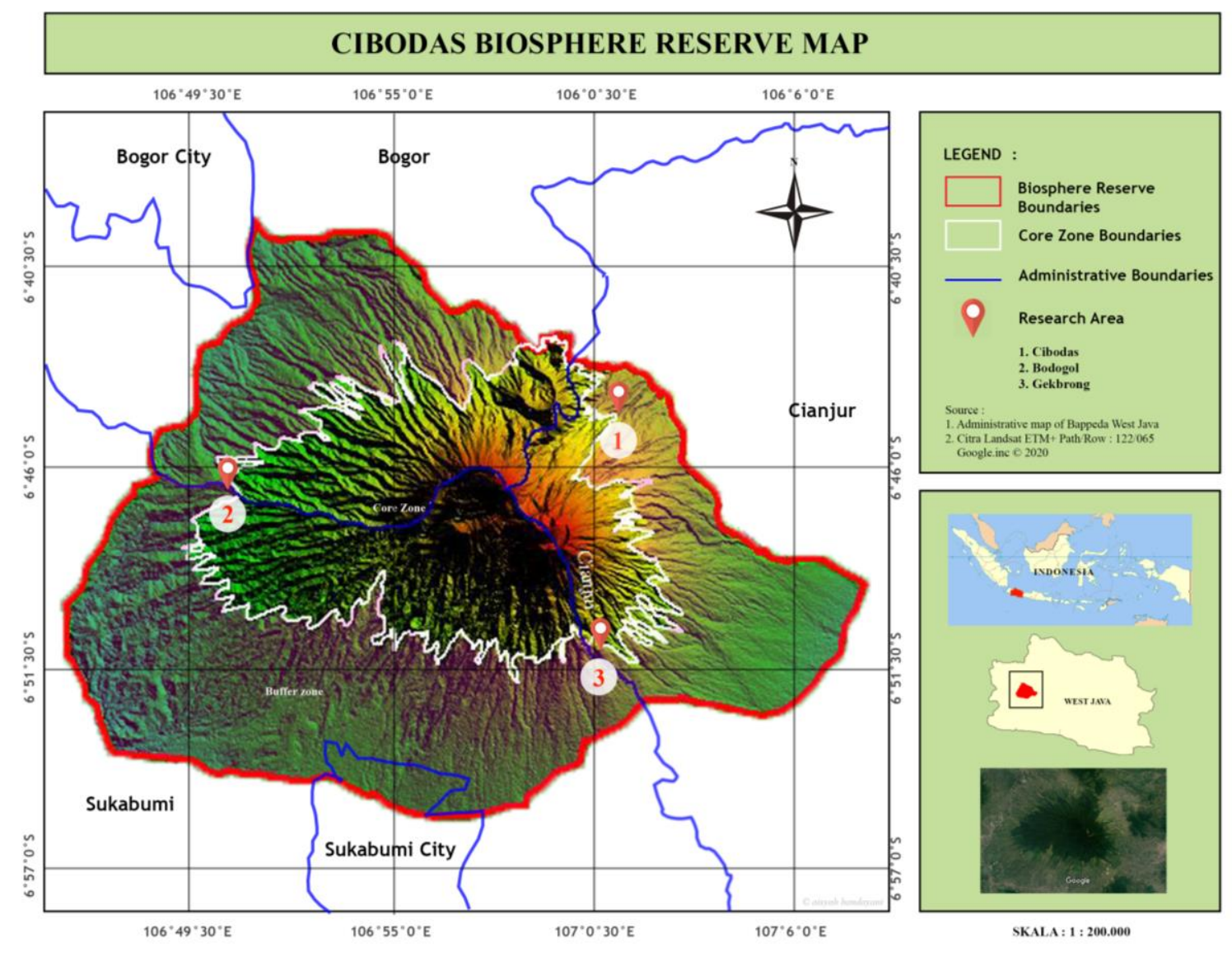

Figure 1. The three research sites in Cibodas Biosphere Reserve, West Java, Indonesia 


\section{Data collections}

A survey was conducted to distribute questionnaire to 90 respondents from all sampling areas. Respondents were chosen by simple random sampling method. We used this sampling type based on the assumption that all residents have equal chances and access to utilizing Naturalized Alien Plant Species (NAPS) in the CBR forest area. Identification of utilized NAPS and its origin based on database of World Flora Online (http://www.worldfloraonline.org/) (WFO 2021) and Plants of the World Online by the Royal Botanic Gardens, Kew (http://www.plantsoftheworldonline.org/) (POWO 2021). The questionnaire was designed to capture the data needed to calculate/quantify the Index Cultural Significance (Turner 1988). The information filled in the questionnaire by the respondent consisted of personal information (i.e., age, gender, education, and occupation), category of utilization of the NAPS (i.e., medicine, food and other food as raw or cooked vegetables, ornamental plant, dye, aromatic and flavoring, fodder, firewood, functional food, timber, recreation, culture/tradition purposes, and other purposes), part of the plant being utilized (i.e., leaves, fruits, seeds, trunks, barks, flowers, roots and all parts of the plant), utilization processes if used as traditional medicine, where these species collected from (i.e., yard, farm, forest edges, and in the forest area), the intensity of this utilization (scores: 1-5), and the level of preference of this utilization (scores: 0,5, 1, and 2).

\section{Data analysis}

The Index of Cultural Significance (ICS) is a proper quantitative method to determine the value of utilized species by communities (Turner 1988). The ICS data can be obtained from interviews or questionnaires targeted to relevant respondents. The ICS value is calculated from the quantification of the categorization of species utilization (e.g., primary or secondary food, flavoring, animal food, primary or secondary material, dye, firewood, medicine, spiritual use, and miscellaneous), the intensity of use, and the species' exclusivity (Turner 1988). The intensity of use and exclusivity level are estimated subjectively based on the respondents' assessment of the used species. The more it is used and the more irreplaceable, the higher its ICS value.

Assessment with the ICS framework can identify the importance of Naturalized Alien Plant Species (NAPS) in the community observed in this study. The collected data from the questionnaire were processed in Microsoft Excel to extract the respondent profiles, the utilized NAPS, category of utilization, part of the plant that utilized, location of collected NAPS, and ICS scores. The ICS score/value was calculated using the following formula (Turner 1988):

$$
\mathrm{ICS}=\sum_{i=1}^{n}(q \times i \times e) u_{i}
$$

Where: ICS is Index of Cultural Significance, $q$ is utilization quality, $i$ is utilization intensity, $e$ is utilization exclusivity, and $n$ is utilization category (1 to $n$ ).
The result of ICS calculation then was classified based on the following categorization proposed by Turner (1988): ICS > 100 (very high significance), 50-99 (high significance), 20-49 (medium significance), 5-19 (low significance), 1-4 (very low significance).

\section{RESULTS AND DISCUSSION}

\section{The utilization of naturalized alien plant species}

Based on questionnaire results, as many as 72 Naturalized Alien Plant Species (NAPS) from 25 families were utilized by local communities in CBR (Table 1). More than $30 \%$ of these utilized species belong to Asteraceae family (Figure 2). In this study, Asteraceae that were frequently utilized are: Ageratum conyzoides, Artemisia vulgaris, Bidens pilosa, Cosmos caudatus, Galinsoga parviflora and Spilanthes acmella. Asteraceae is the most prominent dicot family due to their widespread distribution, fast evolution, and high adaptation capacity to a new environment, making this family easy to be found everywhere and indicates that Asteraceae has a robust invasion mechanism (Carlquist 1976). Many studies have recorded the utilization of Asteraceae species as traditional medicine and food source. However, the studies of Asteraceae capacity to generate secondary metabolites are still understudied, and commercial product from this Asteraceae utilization is still limited (Panda et al. 2019). Asteraceae species also have potential use as organic pesticides due to their allelopathic capacities (Benvenuti et al. 2017).

Among the three surveyed sites, Cibodas had the highest utilization activities (i.e., 14 utilization activities per respondent on average) and the number of NAPS (i.e., 69 species) (Table 2). There are several possible explanations for these findings. First, the respondents in Cibodas mostly had farmland and yard areas where NAPS occurred. Second, several respondents who collected NAPS from the forest edges of GGPNP mostly come from the Cibodas area. Third, several respondents are Cibodas Botanic Gardens staff who have adequate understanding and knowledge about plants, including NAPS, and its utilizations for food, medicinal, and ornamental plants.

Based on the survey results, the most frequent NAPS utilization was for medicine, followed by ornamental plants, food, and fodder (Figure 3). There were 50 species utilized as medicine, 49 species as ornamental plants, 29 species as food and fodder. From a total of 50 species utilized as traditional medicine, the top five of the mostutilized ones were Ageratum conyzoides, Centella asiatica, Artemisia vulgaris, Kalanchoe pinnata, and Physalis peruviana (Table 1). Almost all of these species were utilized in all three survey locations, except for Artemisia vulgaris which were utilized at Bodogol and Cibodas only. Traditional medicine utilization was mainly to cure indigestion, sprue, body sore, fever, and skin diseases. Ageratum conyzoides was used to treat the wound and reduce gastritis, Artemisia vulgaris to eliminate body odor, Kalanchoe pinnata to reduce fever, and Physalis peruviana to treat muscle aches and pains. 
Table 1. List of Naturalized Alien Plant Species (NAPS), geographical origin and utilization by respondents in Cibodas Biosphere Reserve, West Java, Indonesia

\begin{tabular}{|c|c|c|c|c|}
\hline Species & Family & Lifeform & Origin of the species* & $\begin{array}{l}\text { Utilization } \\
\text { category }\end{array}$ \\
\hline Ageratina riparia (Regel) R.M.King \& H.Rob. & Asteraceae & Herbs & Mexico & $\begin{array}{l}\mathrm{F}, \mathrm{M}, \mathrm{O}, \mathrm{D}, \mathrm{Fd}, \mathrm{OF} \\
\mathrm{Fw}, \mathrm{Ot}\end{array}$ \\
\hline Ageratum conyzoides $(\mathrm{L}.) \mathrm{L}$. & Asteraceae & Herbs & Mexico & $\mathrm{F}, \mathrm{M}, \mathrm{O}, \mathrm{Fd}$ \\
\hline Ageratum houstonianum Mill. & Asteraceae & Herbs & Mexico to Central America & $\mathrm{F}, \mathrm{M}, \mathrm{Fd}$ \\
\hline Amaranthus spinosus L. & Amaranthaceae & Herbs & Mexico to Tropical America & $\mathrm{F}, \mathrm{M}, \mathrm{D}, \mathrm{Fd}, \mathrm{OF}$ \\
\hline Artemisia vulgaris $\mathrm{L}$. & Asteraceae & Herbs & $\begin{array}{l}\text { Temperate Eurasia to Indo-China, } \\
\text { North Africa }\end{array}$ & $\mathrm{F}, \mathrm{M}, \mathrm{O}, \mathrm{Fd}, \mathrm{OF}, \mathrm{Fw}$ \\
\hline $\begin{array}{l}\text { Austroeupatorium inulaefolium (Kunth) } \\
\text { R.M.King \& H.Rob. }\end{array}$ & Asteraceae & Shrub & $\begin{array}{l}\text { Panama to South Tropical America, } \\
\text { Trinidad }\end{array}$ & $\mathrm{M}, \mathrm{Fd}, \mathrm{Fw}, \mathrm{Ot}$ \\
\hline Bartlettina sordida (Less.) R.M.King \& H.Rob. & Asteraceae & Shrub & Mexico to Guatemala & $\mathrm{O}$ \\
\hline Bellucia pentamera Naudin & Melastomataceae & Tree & Mexico to S. Tropical America & $\mathrm{F}, \mathrm{O}$ \\
\hline Bidens pilosa $\mathrm{L}$. & Asteraceae & Herbs & Topical, Subtropical America & $\mathrm{F}, \mathrm{M}, \mathrm{O}, \mathrm{Fd}, \mathrm{OF}, \mathrm{P}$ \\
\hline Browallia americana $\mathrm{L}$. & Solanaceae & Herbs & Central Mexico to Tropical America & $\mathrm{O}$ \\
\hline $\begin{array}{l}\text { Brugmansia candida Pers. } \\
\text { syn. Brugmansia x candida Pers. }\end{array}$ & Solanaceae & Tree & S. Colombia to Ecuador & $\mathrm{M}, \mathrm{O}, \mathrm{Fw}$ \\
\hline Brugmansia suaveolens (Willd.)f Sweet & Solanaceae & Tree & Brazil & $\mathrm{M}, \mathrm{O}, \mathrm{OF}, \mathrm{Fw}, \mathrm{Ot}$ \\
\hline Brugmansia versicolor Lagerh. & Solanaceae & Tree & W. Ecuador & $\mathrm{O}, \mathrm{Fw}$ \\
\hline $\begin{array}{l}\text { Calathea lietzei É. Morren } \\
\text { syn. Maranta lietzei (E.Morren) C.H.Nelson, } \\
\text { Sutherl. \& Fern.Casas }\end{array}$ & Marantaceae & Herbs & E. Brazil & $\mathrm{O}$ \\
\hline Calliandra calothyrsus Meisn & Fabaceae & Shrub & South Mexico to Central America & $\begin{array}{l}\mathrm{F}, \mathrm{O}, \mathrm{Fd}, \mathrm{OF}, \mathrm{T}, \mathrm{Fw} \\
\text { Ot }\end{array}$ \\
\hline Centella asiatica (L.) Urb. & Apiaceae & Herbs & $\begin{array}{l}\text { Caucasus, Old World to New } \\
\text { Zealand, South West Pacific }\end{array}$ & $\mathrm{F}, \mathrm{M}, \mathrm{O}, \mathrm{Fd}, \mathrm{OF}$ \\
\hline Cerastium glomeratum Thuill. & Caryophyllaceae. & Herbs & Europe, Macaronesia to Assam & $\mathrm{O}, \mathrm{Ot}$ \\
\hline Cestrum aurantiacum Lindl. & Solanaceae & Shrub & Mexico to Venezuela & $\mathrm{M}, \mathrm{O}, \mathrm{Fw}$ \\
\hline Cestrum elegans (Brongn. ex Neumann) Schltdl. & Solanaceae & Shrub & Mexico & $\mathrm{M}, \mathrm{O}^{\prime}$ \\
\hline $\begin{array}{l}\text { Chimonobambusa quadrangularis (Fenzl) } \\
\text { Makino }\end{array}$ & Poaceae & Bamboo & SE. China to Vietnam, Taiwan & $\begin{array}{l}\mathrm{F}, \mathrm{O}, \mathrm{OF}, \mathrm{T}, \mathrm{Fw}, \mathrm{P} \\
\mathrm{Ot}\end{array}$ \\
\hline Cinchona pubescens Vahl & Rubiaceae & Tree & Costa Rica to W. South America & $\mathrm{M}, \mathrm{T}, \mathrm{FW}$ \\
\hline Clibadium surinamense $\mathrm{L}$. & Asteraceae & Shrub & Tropical America & $\mathrm{Fd}, \mathrm{Fw}$ \\
\hline Clidemia hirta (L.) D. Don & Melastomataceae & Shrub & Mexico to Tropical America & $\mathrm{F}, \mathrm{M}, \mathrm{O}, \mathrm{D}, \mathrm{Fd}, \mathrm{OF}$ \\
\hline Cobaea scandens Cav. & Polemoniaceae & Climber & Mexico & $\mathrm{M}, \mathrm{O}$ \\
\hline Cosmos caudatus Kunth. & Asteraceae & Herbs & Mexico to South Tropical America & $\mathrm{F}, \mathrm{M}, \mathrm{O}, \mathrm{C}, \mathrm{Fd}, \mathrm{OF}$ \\
\hline $\begin{array}{l}\text { Cyphomandra betacea (Cav.) Sendtn. } \\
\text { syn. Solanum betaceum Cav. }\end{array}$ & Solanaceae & Shrub & S. Tropical America & $\mathrm{F}, \mathrm{M}, \mathrm{O}, \mathrm{OF}$ \\
\hline $\begin{array}{l}\text { Dichrocephala bicolor Schltdl. syn. } \\
\text { Dichrocephala integrifolia (L.f.) Kuntze }\end{array}$ & Asteraceae & Herbs & Turkey-in-Europe to Asia, Pacific & $\mathrm{Fd}$ \\
\hline Dracaena fragrans (L.) Ker Gawl. & Asparagaceae & Shrub & Tro & $\mathrm{M}, \mathrm{O}, \mathrm{Ot}$ \\
\hline Drymaria cordata (L.) Willd. ex Schult. & Caryophyllaceae & Herbs & $\begin{array}{l}\text { Mexico to S. Tropical America, } \\
\text { Tropical, S. Africa }\end{array}$ & $\mathrm{O}$ \\
\hline Emilia sonchifolia (L.) DC. ex DC. & Aster & $\mathrm{rbs}$ & Old world & $\mathrm{F}, \mathrm{M}, \mathrm{O}, \mathrm{OF}$ \\
\hline Erechtites valerianifolius (Wolf) DC. & Asteraceae & Herbs & Mexico to Tropi & $\mathrm{F}, \mathrm{M}, \mathrm{O}, \mathrm{Fd}, \mathrm{OF}$ \\
\hline Eryngium foetidum $\mathrm{L}$. & Apiaceae & Herbs & Mexico to Tropi & $\mathrm{F}, \mathrm{M}, \mathrm{OF}, \mathrm{Ot}$ \\
\hline Euphorbia hirta L. & Euphorbiaceae & Herbs & Tropical, Subtropical America & $\mathrm{F}, \mathrm{M}$ \\
\hline Euphorbia prostrata Aiton & Euphorbiaceae & Herbs & Macaronesia to West Siberia, Pakistan & $\mathrm{F}, \mathrm{Fd}$ \\
\hline Fragaria vesca $\mathrm{L}$. & Rosaceae & Herbs & Europe & $\mathrm{F}, \mathrm{M}, \mathrm{O}, \mathrm{D}, \mathrm{Fd}, \mathrm{Ot}$ \\
\hline Galinsoga parviflora Cav. & Asteraceae & Herbs & Mexico to $\operatorname{Tr}$ & $\mathrm{M}, \mathrm{Fd}$ \\
\hline Gnaphalium purpureum L. & Asteraceae & Herbs & E. Canada to Tropical America & $\mathrm{O}$ \\
\hline Hyptis brevipes Poit. & Lamiaceae & Herbs & Southeast Mexico to Tropical America & $\mathrm{Fd}, \mathrm{P}$ \\
\hline Indigofera suffruticosa Mill. & Fabaceae & Shrub & Tropical, Subtropical America & M, D \\
\hline $\begin{array}{l}\text { Kalanchoe pinnata (Lam.) Pers. syn. } \\
\text { Bryophyllum pinnatum (Lam.) Oken }\end{array}$ & Crassulaceae & Herbs & Madagascar & $\mathrm{M}, \mathrm{O}$ \\
\hline Lantana camara $\mathrm{L}$. & Verbenaceae & Shrub & Mex & $\mathrm{O}, \mathrm{P}$ \\
\hline Maesopsis eminii Engl. & Rhamnaceae & Tree & Liberia to South Sudan, Zambia & $\mathrm{Fd}, \mathrm{T}, \mathrm{Fw}, \mathrm{Ot}$ \\
\hline Melastoma malabathricum $\mathrm{L}$. & Melastomataceae & Shrub & $\begin{array}{l}\text { Seychelles, Tropical and Subtropical } \\
\text { Asia to N. and E. Australia }\end{array}$ & $\mathrm{F}, \mathrm{M}, \mathrm{O}, \mathrm{D}, \mathrm{Fd}, \mathrm{Fw}$ \\
\hline Mentha arvensis L. & $\mathrm{Lal}$ & Herbs & Europe to Kamchatka, Nepal & $\mathrm{F}, \mathrm{M}, \mathrm{O}, \mathrm{Fv}, \mathrm{OF}$ \\
\hline Mikania cordata (Burm.f.) B.L.Rob. & Asteraceae & Climber & Old World & $\mathrm{M}, \mathrm{Fd}$ \\
\hline Oxalis barrelieri L. & Oxalidaceae & Herbs & Tropical Am & $\mathrm{F}, \mathrm{M}, \mathrm{O}, \mathrm{Fv}$ \\
\hline Oxalis corniculata $\mathrm{L}$. & Oxalidaceae & Herbs & Mexico, Venezuela, Peru, Caribbean & $\mathrm{F}, \mathrm{M}, \mathrm{O}, \mathrm{Fv}, \mathrm{Ot}$ \\
\hline Oxalis latifolia Kunth. & Oxalidaceae & Herbs & Tropical and Subtropical America & $\mathrm{F}, \mathrm{M}, \mathrm{Fv}, \mathrm{OF}$ \\
\hline
\end{tabular}




\begin{tabular}{|c|c|c|c|c|}
\hline Passiflora edulis Sims & Passifloraceae & Climber & Brazil to North-East Argentina & $\mathrm{F}, \mathrm{M}, \mathrm{O}, \mathrm{OF}$ \\
\hline Passiflora ligularis Juss & Passifloraceae & Climber & Panama to Venezuela, Peru & $\mathrm{F}, \mathrm{M}, \mathrm{O}$ \\
\hline Passiflora suberosa L. & Passifloraceae & Climber & Caribbean & $\mathrm{F}, \mathrm{M}, \mathrm{O}$ \\
\hline Physalis peruviana $\mathrm{L}$. & Solanaceae & Herbs & Bolivia to West Brazil & $\mathrm{F}, \mathrm{M}, \mathrm{O}, \mathrm{Fd}$ \\
\hline Piper aduncum L. & Piperaceae & Tree & Mexico to Tropical America & $\mathrm{M}, \mathrm{O}, \mathrm{Fd}, \mathrm{Fw}$ \\
\hline Podachaenium eminens (Lag.) Sch.Bip. ex Sch.Bip. & Asteraceae & Shrub & Mexico to Colombia & Fw, Ot \\
\hline Salvia hispanica $\mathrm{L}$. & Lamiaceae & Herbs & Mexico to Ecuador & $\mathrm{O}$ \\
\hline Sida rhombifolia $\mathrm{L}$. & Malvaceae & Shrub & Tropical and Subtropical Old World & $\mathrm{F}, \mathrm{M}, \mathrm{O}, \mathrm{Fd}, \mathrm{Ot}$ \\
\hline Solanum aculeatissimum Jacq. & Solanaceae & Shrub & $\begin{array}{l}\text { Southeast and South Brazil to South } \\
\text { Central Paraguay }\end{array}$ & $\mathrm{O}$ \\
\hline Solanum americanum Mill. & Solanaceae & Herbs & New World & $\mathrm{F}, \mathrm{M}, \mathrm{D}, \mathrm{Fd}, \mathrm{OF}, \mathrm{Ot}$ \\
\hline Solanum torvum $\mathrm{Sw}$. & Solanaceae & Shrub & $\begin{array}{l}\text { Mexico to South America, } \\
\text { Caribbean,, East Brazil }\end{array}$ & $\mathrm{F}, \mathrm{M}, \mathrm{O}, \mathrm{Fd}, \mathrm{OF}, \mathrm{Fw}$ \\
\hline $\begin{array}{l}\text { Solanum verbascifolium Kunth syn. Solanum } \\
\text { bicolor Willd. }\end{array}$ & Solanaceae & Shrub & $\begin{array}{l}\text { Florida, Bahamas, Texas to } \\
\text { Guatemala }\end{array}$ & $\mathrm{M}, \mathrm{Fw}$ \\
\hline Sonchus arvensis $\mathrm{L}$. & Asteraceae & Herbs & Europe to Siberia, Caucasus & $\mathrm{M}, \mathrm{Fd}$ \\
\hline Sonchus asper (L.) Hill & Asteraceae & Herbs & $\begin{array}{l}\text { Temp. Eurasia, N. Africa to Sahel, } \\
\text { Somalia }\end{array}$ & M \\
\hline Sonchus oleraceus (L.) L. & Asteraceae & Herbs & $\begin{array}{l}\text { Macaronesia, Europe to Medit., } \\
\text { Sahara to Arabian Peninsula }\end{array}$ & $\mathrm{M}, \mathrm{OF}$ \\
\hline Spilanthes acmella (L.) L. & Asteraceae & Herbs & $\begin{array}{l}\text { Tropical and Subtropical Asia to } \\
\text { Queensland (Torres Strait Islands) }\end{array}$ & $\mathrm{F}, \mathrm{M}, \mathrm{Fd}, \mathrm{OF}$ \\
\hline Stachytarpheta jamaicensis (L.) Vahl & Verbenaceae & Shrub & East USA to Tropical America & M \\
\hline Stellaria media (L.) Vill. & Caryophyllaceae. & Herbs & $\begin{array}{l}\text { Temp. Eurasia, N. and NE. Tropical } \\
\text { Africa }\end{array}$ & M \\
\hline $\begin{array}{l}\text { Taraxacum officinale (L.) Weber ex F.H.Wigg. } \\
\text { syn. Taraxacum campylodes G.E. Haglund }\end{array}$ & Asteraceae & Herbs & East USA to Tropical America & $\mathrm{M}, \mathrm{O}, \mathrm{OF}$ \\
\hline Tetrapanax papyrifer (Hook.) K.Koch & Araliaceae & Shrub & Central and S. China, Taiwan & $\mathrm{O}$ \\
\hline Thunbergia coccinea Wall. & Acanthaceae & Climber & $\begin{array}{l}\text { Indian Subcontinent to China } \\
\text { (Yunnan), Indo-China }\end{array}$ & $\mathrm{O}$ \\
\hline Tithonia rotundifolia (Mill.) S.F.Blake & Asteraceae & Shrub & Mexico to Central America & $\mathrm{M}, \mathrm{O}$ \\
\hline Viola odorata $\mathrm{L}$. & Violaceae & Herbs & Europe to W. and N. Iran, NW. Africa & $\mathrm{M}, \mathrm{O}$ \\
\hline $\begin{array}{l}\text { Wedelia trilobata }(\text { L.) Hitchc. syn. } \\
\text { Sphagneticola trilobata (L.) Pruski }\end{array}$ & Asteraceae & Herbs & $\begin{array}{l}\text { Mexico to S. Tropical America, } \\
\text { Trinidad }\end{array}$ & $\mathrm{M}, \mathrm{O}, \mathrm{Fd}, \mathrm{Fw}$ \\
\hline
\end{tabular}

Table 2. The number of respondents, utilized Naturalized Alien Plant Species (NAPS) and the type of utilization across the surveyed sites in Cibodas Biosphere Reserve, West Java, Indonesia

\begin{tabular}{lccc}
\hline & Bodogol & Cibodas & Gekbrong \\
\hline$\sum$ Respondents & 22 & 39 & 29 \\
E Utilized NAPS & 25 & 69 & 39 \\
Average of utilization per respondent & 3.32 & 13.77 & 1.93 \\
\hline
\end{tabular}

The most utilized NAPS for food were Passiflora ligularis, Passiflora edulis, Fragaria vesca, and Physalis peruviana as the source of fruits. Solanum americanum, Centella asiatica, Amaranthus spinosus, Mentha arvensis, Chimonobambusa quadrangularis were utilized as vegetable sources.

Centella asiatica (local name: antanan) was the most utilized NAPS with the most frequent use for medicine and food source (Table 3). The utilization of $C$. asiatica as medicine and food is already recorded in many plant utilization studies in Indonesia (Wakhidah and Mustaqim 2020). Based on many clinical tests, $C$. asiatica can cure neurological diseases and skin diseases (Sun et al. 2020). Related to its invasive characters, $C$. asiatica can quickly propagate vegetatively, have a high growth rate, and is a shade-tolerant species but also grows under full sun conditions, adaptable in different soil conditions, and a cosmopolitan species that occurs from 300 to $1450 \mathrm{~m}$ asl. (CABI 2020; Devkota and Jha 2009; PIER 2014). Even though $C$. asiatica is classified as high risk based on invasiveness scoring, there is no report about the negative impact of this species on economy yet (CABI 2020; PIER 2014).

The most commonly used part of the plant in NAPS utilization in CBR was the leaves (Figure 4). The sensible explanation for this result is that leaves are more abundant than other plant's parts and are easier to collect. The many uses of the leaves of NAPS cause no need for the cultivation of these species since the leaves can be harvested from wild plants. Another part that been used quite large was all parts of the plant. This method is usually applied to herbaceous plants. 
Table 3. List of top ten utilized Naturalized Alien Plant Species (NAPS) (10 out of 72) in Cibodas Biosphere Reserve, West Java, Indonesia the highest number of utilization activities

\begin{tabular}{lllcc}
\hline Species & Family & Local names & $\begin{array}{c}\text { Number of utilization } \\
\text { activities }\end{array}$ & $\begin{array}{c}\text { Number of } \\
\text { respondents }\end{array}$ \\
\hline Centella asiatica (L.) Urb. & Apiaceae & Antanan & 83 & 38 \\
Calliandra calothyrsus Meisn & Fabaceae & Kaliandra & 58 & 24 \\
Ageratum conyzoides (L.) L. & Asteraceae & Babadotan & 50 & 37 \\
Chimonobambusa quadrangularis (Fenzl) Makino & Poaceae & Kirisi & 47 & 20 \\
Mentha arvensis L. & Lamiaceae & Keresmen & 44 & 24 \\
Artemisia vulgaris L. & Asteraceae & Artemisia & 43 & 23 \\
Cosmos caudatus Kunth. & Asteraceae & Ramidang & 41 & 16 \\
Kalanchoe pinnata (Lam.) Pers. syn. & Crassulaceae & Cocor bebek & 34 & 22 \\
Bryophyllum pinnatum (Lam.) Oken & Amaranthaceae & Bayem & 33 & 16 \\
Amaranthus spinosus L. & Asteraceae & Hareuga & 33 & 16 \\
Bidens pilosa L. & & & & \\
\hline
\end{tabular}

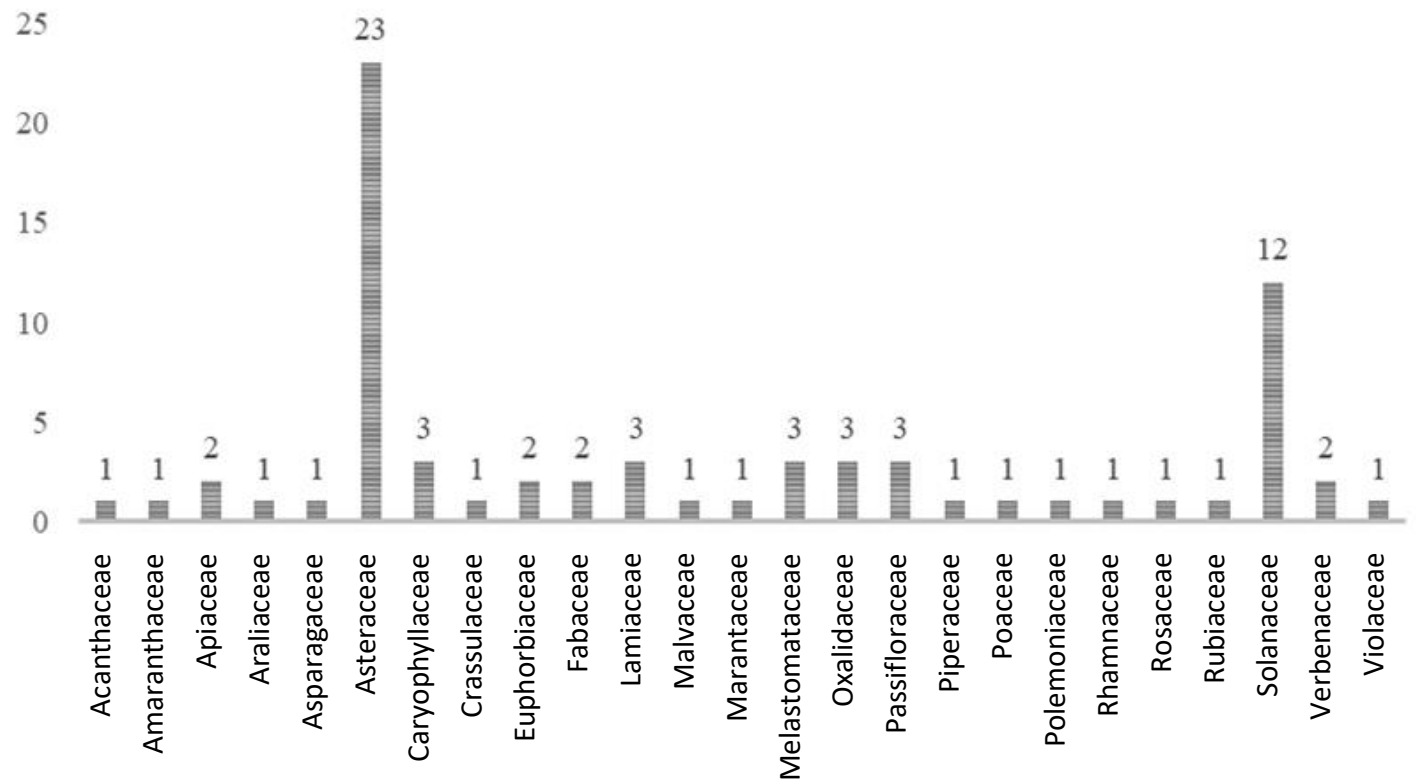

Figure 2. The number of utilized Naturalized Alien Plant Species (NAPS) in Cibodas Biosphere Reserve, West Java, Indonesia across family

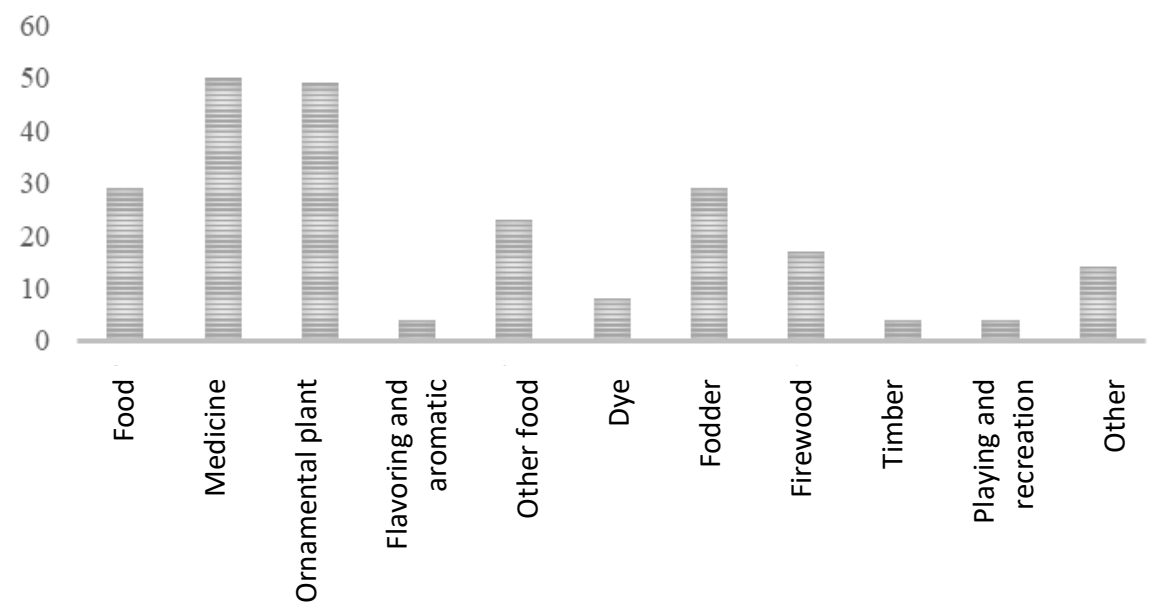

Figure 3. The number of utilized Naturalized Alien Plant Species (NAPS) in Cibodas Biosphere Reserve, West Java, Indonesia based on utilization categories 


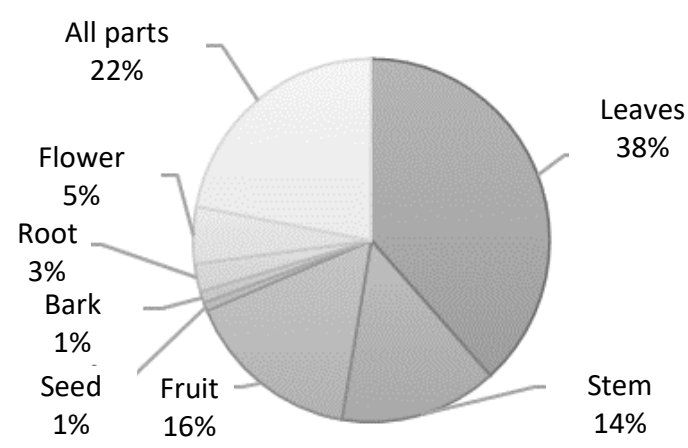

Figure 4. The proportion of the plant part of utilized Naturalized Alien Plant Species (NAPS) in Cibodas Biosphere Reserve, West Java, Indonesia

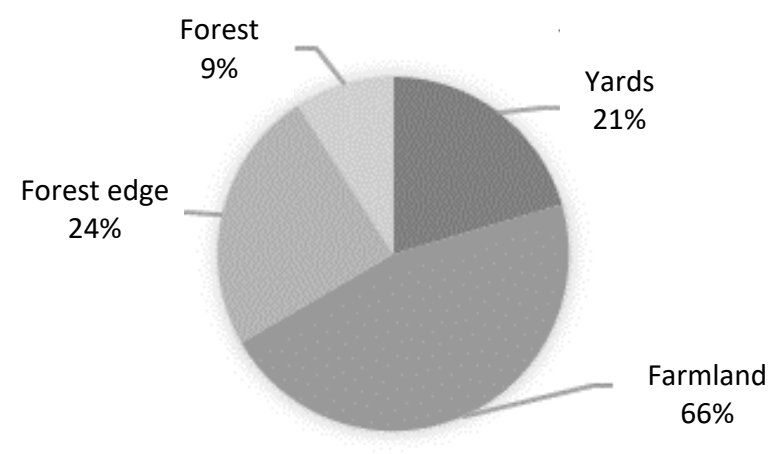

Figure 6. The proportion of the collection site of utilized Naturalized Alien Plant Species (NAPS) in Cibodas Biosphere Reserve, West Java, Indonesia

Based on the life form, most utilized NAPS were in the form of herbaceous plants (Figure 5). This is not surprising since herbaceous plants can be easily obtained, easy to harvest, and easy to process.

Based on the questionnaire results, most of the utilized NAPS were collected from farmland $(46 \%)$ and followed by forest edges (24\%) (Figure 6). From 72 plant species, only eight species were obtained from forest areas in which these eight taxa had low utilization rates. Based on that data, the NAPS utilization activity does not significantly impact the NAPS population in the forest area.

\section{Index of Cultural Significance (ICS)}

Based on the calculation of Index of Cultural Significance (ICS), the utilized NAPS in Cibodas Biosphere Reserve can be classified as four: high significance (14\% or 10 species), moderate significance ( $24 \%$ or 17 species), low significance ( $42 \%$ or 30 species), and very low significance (20\% or 15 species). Most of the high significance taxa were utilized for food sources and traditional medicine. This finding is in concordance with da Rocha Silva and de Holanda Cavalcante Andrade (2006), which stated that plant-utilized species for food sources and

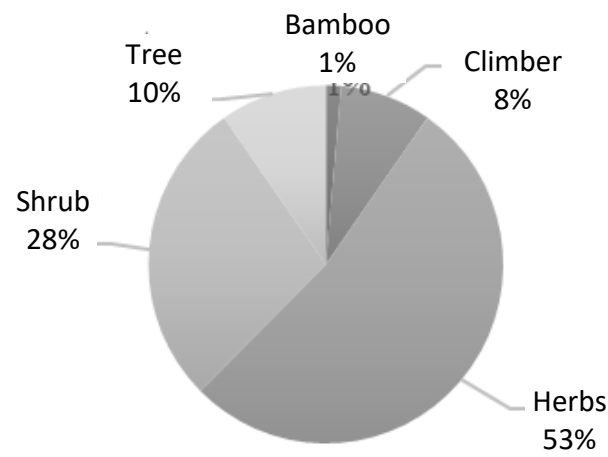

Figure 5. The proportion of lifeform of utilized Naturalized Alien Plant Species (NAPS) in Cibodas Biosphere Reserve, West Java, Indonesia

medicine have relatively high ICS scores than other purposes. These utilized NAPS with high ICS scores were mostly common plants on farmland or yards area, including Artemisia vulgaris, Mentha arvensis, Centella asiatica, Cyphomandra betacea, Fragaria vesca, and Solanum torvum.

The utilized NAPS with the highest ICS score was Artemisia vulgaris (Table 4). This species was primarily utilized as a food source and traditional medicine. There were 23 respondents who utilized A. vulgaris as food and medicine. This species is a well-known traditional medicinal plant. In the middle ages, A. vulgaris was known as "mother of herbs" due to their importance and significance in medicine's history (Ekiert et al. 2020). The Greek language took the genus name Artemisia from Artemis, a God that protects pregnant and gives birth's mothers (Ekiert et al. 2020).

Artemisia vulgaris is an introduced exotic species in Java. In the context of Cibodas Botanic Gardens history, during the 1800s (between 1840-1850), there were a massive exotic plant introduction in Cibodas Botanic Gardens area and its adjacent Mount Gede-Pangrango forests. Among these introduced species were Fragaria vesca (strawberry), Rubus spp. and Cinchona pubescens (quinine) (van Steenis and van Steenis-Kruseman 1953). Ekiert et al. (2020) stated that herbal material from $A$. vulgaris has essential oil content and other bio-active compounds. The essential oil content is used as a raw material in the cosmetic and food industries (Ekiert et al. 2020).

The result of ICS also in concordance with the intensity of NAPS utilization. NAPS with high ICS scores were highly used species. These species were Centella asiatica, Calliandra calothyrsus, Chimonobambusa quadrangularis, Mentha arvensis, Artemisia vulgaris, Amaranthus spinosus, and Bidens pilosa. Supiandi et al. (2019) stated that species with high ICS scores tend to be maintained by communities. Based on that, it certainly needs management to control the population of utilized NAPS to prevent their risk of invasion. 
Table 4. The top ten utilized Naturalized Alien Plant Species (NAPS) in Cibodas Biosphere Reserve with the highest score of Index of Cultural Significance (ICS)

\begin{tabular}{|c|c|c|c|c|c|}
\hline Species name & Local name & Family & ICS & $\begin{array}{c}\text { Number of } \\
\text { utilization activities }\end{array}$ & $\begin{array}{l}\text { Number of } \\
\text { respondents }\end{array}$ \\
\hline Artemisia vulgaris $\mathrm{L}$. & Lokatmala & Asteraceae & 98.32 & 43 & 23 \\
\hline Chimonobambusa quadrangularis (Fenzl) Makino & Kirisi & Poaceae & 76.52 & 29 & 20 \\
\hline Bidens pilosa $\mathrm{L}$. & Hareuga & Asteraceae & 67.81 & 47 & 16 \\
\hline Mentha arvensis $\mathrm{L}$. & Keresmen & Lamiaceae & 63.39 & 33 & 24 \\
\hline Amaranthus spinosus $\mathrm{L}$. & Bayam & Amaranthaceae & 61.14 & 44 & 16 \\
\hline Centella asiatica (L.) Urb. & Antanan & Apiaceae & 60.17 & 33 & 38 \\
\hline $\begin{array}{l}\text { Cyphomandra betacea (Cav.) Sendtn. syn. } \\
\text { Solanum betaceum Cav. }\end{array}$ & $\begin{array}{l}\text { Terong } \\
\text { belanda }\end{array}$ & Solanaceae & 55.04 & 24 & 13 \\
\hline Calliandra calothyrsus Meisn. & Kaliandra & Fabaceae & 54.24 & 58 & 24 \\
\hline Fragaria vesca L. & Stroberi & Rosaceae & 53.62 & 29 & 21 \\
\hline Solanum torvum $\mathrm{Sw}$. & Takokak & Solanaceae & 50.29 & 31 & 21 \\
\hline
\end{tabular}

Zimdahl (2018) stated that the same plant could act as a weed in one place and as a beneficial plant in another. This statement means that if these NAPS are found in some locations as an invasive species, it could be that the species is not invasive in other places, even beneficial both socialeconomically or ecology. For example, Calliandra calothyrsus is commonly used for landslide mitigation (Zakaria et al. 2013; Hairiah et al. 2020) and also suitable for wood energy as renewable energy in anticipating decreasing fossil energy resources (Hendrati and Nurrohmah 2019). From this study, we only knew the benefits and levels of NAPS utilization in CBR, while studies of the invasion risk from these NAPS have not been carried out. There are only a few studies on NAPS' ecological condition in the GGPNP forest area. For example, the high population and diversity of alien plant species around the trail (Padmanaba et al. 2017), the distribution of Cobaea scandens in riparian part of Cibodas Botanic Garden areas (Efendi et al. 2019) and the spread of Chimonobambusa quadrangularis from the Cibodas Botanical Garden into the forest area GGPNP (Damayanto and Muhaimin 2017). Therefore, it is necessary to assess the risk level of invasion of these species, whether the risk level of invasion is higher or lower than the economic and cultural benefits.

A study by Kannan et al. (2016) showed that the use of L. camara in a village in South India was proven to help control this species' population. Without any cultivation activities, this species is harvested periodically for making handicrafts so that such activities can control the population of $L$. camara. Based on that case, a conventional management program could incorporate utilization strategy as several approaches towards NAPS management. The advantages of this approach are this is inexpensive method, it can sustain over many years, and more importantly, unlike top-down approach through eradication programs which are usually one-off and maybe not effective in the long run in preventing species recurrence, this method can involve local communities and empower and improve their livelihoods (Kannan et al. 2016).

Wittenberg and Cock (2001) stated four main strategies to deal with alien species that have already established invading populations: eradication, containment, control, and mitigation. Based on these strategies, we recommend to control the population of utilized NAPS in Cibodas Biosphere Reserve by regular harvesting. The community can harvest the species for sale in the traditional market for several high-economic value species. Based on this study, the traditional market in Cibodas area is usually selling seasonal fruit or vegetables, among which are the NAPS recorded in this study. We can also do containment through these utilization activities, which is a management strategy to prevent these NAPS spread more widely. Containment is a deliberate action to prevent the establishment of the species outside a determined area (Grice et al. 2020). Containment is also a management option when eradication cannot be applied or may cause unexpected side effects (Junaedi 2012). Furthermore, Wagh and Jain (2018) stated that in some cases of over-exploitation of native plant species, utilization of alien plant species as an alternative could reduce the pressure on native plant species, thus leading to conservation of the diversity of these native plants.

To conclude, the rate of Naturalized Alien Plant Species (NAPS) utilization in Cibodas Biosphere Reserve (CBR) buffer zone areas was relatively high because local communities utilized more than $80 \%$ of NAPS species in CBR. On the other hand, most of the utilized NAPS were collected from farmland areas. Thus, NAPS' utilization seems not to significantly impact the NAPS population in the CBR core zone, Gunung Gede Pangrango National Park forests. Therefore, utilization of NAPS can be carried out with regular harvesting to control NAPS' population and to prevent the population spread more widely. Also, an assessment of the level risk of NAPS invasion is needed to know which species have a high risk of invasion to prevent the risk arises and harmful to the ecosystem.

\section{ACKNOWLEDGEMENTS}

The authors thank LPDP for the research funding support (FR2682020225854). The authors also thank Muslim from Cibodas, Jamaludin from Bodogol, and Uden from Gekbrong, who assisted the NAPS identification and 
supported all fieldwork activities and the questionnaire survey for data collection.

\section{REFERENCES}

Benvenuti S, Cioni PL, Flamini G, Pardossi A. 2017. Weeds for weed control: Asteraceae essential oils as natural herbicides. Weed Res 57 (5): 342-353. DOI: 10.1111/wre.12266.

CABI. 2020. Invasive Species Compendium: Centella asiatica (Asiatic pennywort). CABI, UK. https://www.cabi.org/isc/datasheet/12048

Carlquist S. 1976. Tribal interrelationships and phylogeny of the Asteraceae. Aliso A J Syst Evol Bot 8 (4): 465-492. DOI: 10.5642/aliso.19760804.10.

Damayanto IPGP, Muhaimin M. 2017. Notes on Chimonobambusa quadrangularis (Franceschi) Makino (Poaceae: Bambusoideae) as an invasive alien plant species in Indonesia. Floribunda 5 (7): 253-257. DOI: 10.32556/floribunda.v5i7.2017.201.

Devkota A, Jha PK. 2009. Variation in growth of Centella asiatica along different soil composition. Bot Res Int 2 (1): 55-60.

Efendi M, Muhaimin M, Suherman D. 2019. Sebaran populasi Cobaea scandens CAV. sebagai tumbuhan invasif di Kebun Raya Cibodas dan sekitarnya. Al-Kauniyah J Biol 12 (1): 103-111. DOI: 10.15408/kauniyah.v12i1.9033.

Ekiert H, Pajor J, Klin P, Rzepiela A, Slesak H, Szopa A. 2020. Significance of Artemisia vulgaris L. (common mugwort) in the history of medicine and its possible contemporary applications substantiated by phytochemical and pharmacological studies. Molecules 25 (19): 1-32. DOI: 10.3390/molecules25194415.

Foxcroft LC, Pyšek P, Richardson DM, Genovesi P, MacFadyen S. 2017. Plant invasion science in protected areas: progress and priorities. Biol Invasions. 19 (5): 1353-1378. DOI: 10.1007/s10530-016-1367-z.

Grice AC, Murphy HT, Clarkson JR, Friedel MH, Fletcher CS, Westcott DA. 2020. A review and refinement of the concept of containment for the management of invasive plants. Aust J Bot 68 (8): 602-616. DOI: 10.1071/BT20092.

Hairiah K, Widianto W, Suprayogo D, Van Noordwijk M. 2020. Tree roots anchoring and binding soil: Reducing landslide risk in Indonesian agroforestry. Land 9 (8): 256. DOI: 10.3390/land9080256

Handayani A, Hidayati S. 2020. Utilization of Invasive Alien Species (IAS) by communities around Cibodas Biosphere Reserve (CBR): A recommendation for invasive alien species management and policy. IOP Conf Ser Earth Environ Sci 533 (1). DOI: 10.1088/17551315/533/1/012017.

Hendrati RL, Nurrohmah SH. 2019. Breeding for better growth of Calliandra calothyrsus Meissn., a fast growing legume for woodenergy. Jurnal Perbenihan Tanaman Hutan 7 (1): 13-20. DOI: 10.20886/bptpth.2019.7.1.13-20.

Jeschke JM, Bacher S, Blackburn TIMM, Dick JTA, Essl F, Evans T, Gaertner M, Hulme PE, Mrugała A, Pergl JAN, et al. 2014. Defining the impact of non-native species. Conserv Biol 28 (5): 1188-1194. DOI: 10.1111/cobi.12299.

Junaedi DI. 2012. Invasive plants in mountainous remnant forest: Recommendation for choosing best decision for invasive species management of Cestrum aurantiacum Lindl. Bul Kebun Raya 15 (1): 37-47. DOI: 10.21009/jgg.011.04.

Junaedi DI, Mutaqien Z. 2018. Predicting invasion probability from botanic gardens using exotic species traits. Biosaintifika J Biol Biol Educ 10 (3): 539-545. DOI: 10.15294/biosaintifika.v10i3.15500.

Kannan R, Shackleton CM, Krishnan S, Shaanker RU. 2016. Can local use assist in controlling invasive alien species in tropical forests? The case of Lantana camara in Southern India. For Ecol Manag 376: 166173. DOI: $10.1016 /$ j.foreco.2016.06.016.

Knezevic SZ. 2017. Invasive Plant Species. In: Thomas B, Murray BG, Murphy DJ (eds) Encyclopedia of Applied Plant Sciences. Elsevier, UK. DOI: 10.1016/B978-0-12-394807-6.00021-6.

Kudo Y, Mutaqien Z, Simbolon H, Suzuki E. 2014. Spread of invasive plants along trails in two national parks in West Java, Indonesia. Tropics 23 (3): 99-110. DOI: 10.3759/tropics.23.99.

Kueffer C. 2017. Plant invasions in the Anthropocene. Science 358 (6364): 724-725. DOI: 10.1126/science.aao6371.

Mutaqien Z, Tresnanovia V, Zuhri M. 2011. Penyebaran tumbuhan asing di hutan Wornojiwo Kebun Raya Cibodas, Cianjur, Jawa Barat. In: Zuhri M, Kurnita NI, Normasiwi S, Lailati M, Destri, Rahman W (eds) Prosiding Seminar Nasional HUT Kebun Raya Cibodas Ke-159. Kebun Raya Cibodas, Cianjur, 7 April 2011. [Indonesian]

Negi GCS, Sharma S, Vishvakarma SCR. 2019. Ecology and use of Lantana camara in India. Bot Rev 85 (2): 109-130. DOI: 10.1007/s12229-019-09209-8.

Padmanaba M, Tomlinson KW, Hughes AC, Corlett RT. 2017. Alien plant invasions of protected areas in Java, Indonesia. Sci Rep 7 (1): 111. DOI: 10.1038/s41598-017-09768-z.

Panda SK, Cláudio L, Sahal D, Leonti M. 2019. Editorial: Ethnopharmacological studies for the development of drugs with special reference to Asteraceae. Front Pharmacol 10: 955. DOI: $10.1038 /$ srep 41254.

PIER. 2014. Pacific Islands ecosystems at risk: Centella asiatica (L.) Urb., Apiaceae. http://www.hear.org/pier/species/centella_asiatica. htm

POWO. 2021. Plants of the World Online. Facilitated by the Royal Botanic Gardens, Kew. http://www.plantsoftheworldonline.org/.

Pyšek P, Hulme, PE, Simberloff D, Bacher S, Blackburn TM, Carlton JT, Dawson W, Essl F, Foxcroft LC, Genovesi P, Jeschke JM,Kuhn I, Liebhold AM, Mandrak NE, Meyerson LA, Pauchard A, Pergi J, Roy HE, Seebens H, van Kleunen M, Vila M, Wingfield MJ, Richardson DM. 2020. Scientists' warning on invasive alien species. Biol Rev 95 (6): 1511-1534. DOI: 10.1111/brv.12627.

Pyšek P, Pergl J, Essl F, Lenzner B, Dawson W, Kreft H, Weigelt P, Winter M, Kartesz J, Nishino M, et al. 2017. Naturalized alien flora of the world: Species diversity, taxonomic and phylogenetic patterns, geographic distribution and global hotspots of plant invasion. Preslia 89 (3): 203-274. DOI: 10.23855/preslia.2017.203.

Rai PK, Kim K. 2020. Invasive alien plants and environmental remediation: A new paradigm for sustainable restoration ecology. Restor Ecol 28 (1): 3-7. DOI: 10.1111/rec.13058.

Rai PK, Singh JS. 2020. Invasive alien plant species: Their impact on environment, ecosystem services and human health. Ecol Indic. 111: 106020. DOI: 10.1016/j.ecolind.2019.106020.

Rai PK, Singh MM. 2015. Lantana camara invasion in urban forests of an Indo-Burma hotspot region and its eco-sustainable management implication through biomonitoring of particulate matter. J Asia-Pac Biodivers 8 (4): 375-381. DOI: 10.1016/j.japb.2015.09.003.

Richardson DM, Pyšek P, Rejmánek M, Barbour MG, Panetta FD, West CJ. 2000. Naturalization and invasion of alien plants: Concepts and definitions. Divers Distrib 6 (2): 93-107. DOI: 10.1046/j.14724642.2000.00083.x

da Rocha Silva AJ, de Holanda CAL. 2006. Cultural significance of plants in communities located in the Coastal Forest Zone of the state of Pernambuco, Brazil. Hum Ecol 34 (3): 447-465. DOI: 10.1007/s10745-006-9026-0.

Setiawan M, Rahayu M, Susiarti S. 2020. Studi etnobotani spesies tumbuhan asing invasif 'konyal' (Passiflora edulis) dan peran ekonominya bagi masyarakat lokal Desa Sarongge, Kabupaten Cianjur, Jawa Barat. Prosiding Seminar Nasional Masyarakat Biodiversitas Indonesia, Bogor, 12 Oktober 2019. [Indonesian]

Shackleton RT, Shackleton CM, Kull CA. 2019. The role of invasive alien species in shaping local livelihoods and human well-being: A review. J Environ Manag 229: 145-157. DOI: 10.1016/j.jenvman.2018.05.007.

Shrestha BB, Shrestha UB, Sharma KP, Thapa-Parajuli RB, Devkota A, Siwakoti M. 2019. Community perception and prioritization of invasive alien plants in Chitwan-Annapurna Landscape, Nepal. J Environ Manag 229: 38-47. DOI: 10.1016/j.jenvman.2018.06.034.

van Steenis CGG, van Steenis-Kruseman M. 1953. Brief sketch of the Tjibodas Mountain Garden. Flora Malesiana Bull 10 (1): 313-348.

Sun B, Wu L, Wu Y, Zhang C, Qin L, Hayashi M, Kudo M, Gao M, Liu T. 2020. Therapeutic potential of Centella asiatica and its triterpenes : A review. Front Pharmacol 11: 1-24. DOI: 10.3389/fphar.2020.568032.

Sunaryo, U T, Tihurua EF. 2012. Jenis tumbuhan asing invasif yang mengancam ekosistem Taman Nasional Gunung Gede Pangrango, Resort Bodogol, Jawa Barat. Berk Penelit Hayati 17: 147-152. DOI: 10.23869/bphjbr.27.2.20124 [Indonesian]

Supiandi MI, Mahanal S, Zubaidah S, Julung H, Ege B. 2019. Ethnobotany of traditional medicinal plants used by Dayak Desa Community in Sintang, West Kalimantan, Indonesia. Biodiversitas 20 (5): 1264-1270. DOI: 10.13057/biodiv/d200516.

Turner NJ. 1988. The importance of a rose: Evaluating the cultural significance of plants in Thompson and Lillooet interior salish. Am Anthropol 90 (2): 272-290. DOI: 10.1525/aa.1988.90.2.02a00020. 
Wagh VV, Jain AK, 2018. Status of ethnobotanical invasive plants in western Madhya. South Afr J Bot 114: 171-180. DOI 10.1016/j.sajb.2017.11.008.

Wakhidah AZ, Mustaqim WA. 2020. Centella asiatica (L.) Urb. Apiaceae. In: Franco FM (ed) Ethnobotany of the Mountain Regions of Southeast Asia. Springer Nature, Switzerland AG. DOI: 10.1007/978-3-030-14116-5_72-1.

WFO. 2021. World Flora Online. Published on the Internet. http://www.worldfloraonline.org.

Wittenberg R, Cock MJ. 2001. Invasive alien species: A toolkit of best prevention and management practices. CABI. DOI 10.1079/9780851995694.0000.
Zakaria Z, Muslim D, Sophian RI, Kuswaryan S, Tanuwirya UH. 2013. Bio-engineering, melalui pemanfaatan tanaman kaliandra (Caliandra calothyrsus) di wilayah zona rawan longsor, Jawa Barat. Bulletin of Scientific Contribution $11 \quad$ (3): 168-175. DOI: 10.24198/bsc\%20geology.v11i3.8297.g3844 [Indonesian]

Zimdahl RL. 2018. Uses of Weeds - Ethnobotany. In: Fernandez BJ (ed) Fundamentals of Weed Science: Fifth Edition. Academic Press, UK. DOI: 10.1016/B978-0-12-811143-7.00004-4. 